\title{
Binding of Dentin Noncollagenous Matrix Proteins to Biological Mineral Crystals: An Atomic Force Microscopy Study
}

\author{
M. L. Wallwork, ${ }^{2}$ J. Kirkham, ${ }^{2}$ H. Chen, ${ }^{2}$ S.-X. Chang, ${ }^{1}$ C. Robinson, ${ }^{2}$ D. A. Smith, ${ }^{3}$ B. H. Clarkson ${ }^{1}$ \\ ${ }^{1}$ University of Michigan School of Dentistry, 1011 N. University, Ann Arbor, Michigan, USA \\ ${ }^{2}$ Leeds Dental Institute, University of Leeds, Leeds, UK \\ ${ }^{3}$ Department Physics and Astronomy, University of Leeds, Leeds, UK
}

Received: 25 January 2001 / Accepted: 7 January 2002 / Online publication: 16 July 2002

Abstract. Noncollagenous matrix proteins (NCPs) of dental hard tissues (dentin, cementum) are involved, both temporally and spatially, in the mineralization of their collagen matrices. Two of the NCPs thought to initiate mineral nucleation and control crystal growth in dentin, are dentin phosphoproteins (DPP) and dentin sialoprotein (DSP). Control of crystal growth would depend on the binding capacity of these two molecules, which may be related to the charge domains on the crystals and/or the phosphorylation of the protein. Phosphophoryn (a highly phosphorylated DPP) and DSP were isolated, purified, and characterized from the immature root apicies of human teeth. Dephosphorylation of phosphophoryn was carried out using bovine intestinal alkaline phosphatase. Enamel crystals were prepared from the maturation stage of developing rat incisor enamel. Protein-coated crystals were prepared for viewing in an atomic force microscope fluid cell using tapping mode. Desorption of the proteins was achieved using a phosphate buffer and surface roughness measurements were obtained from all specimens. Time-lapsed images of the crystals showed "nanospheres" of protein distributed along the crystals but only the phosphophoryn-coated crystals showed a distinctive banding pattern, which was still visible after the phosphate desorption experiments. The surface roughness measurements were statistically greater $(P<0.01)$ when compared to the control for only the phosphophoryn-coated specimens. It is hypothesized that the phosphophoryn binding may be associated with charge arrays on the crystal surface and its phosphorylation. Also, based on its affinity for the crystalsurfaces, phosphophoryn seems the most likely candidate for controlling dentin crystal growth and morphology.

Key words: Dentin - Protein - AFM - Binding Crystals

The successful mineralization of the collagen matrix of dental hard tissues (dentin, cementum) during tooth development and repair is exquisitely dependent on the sequencing of a series of genetic and biochemical events. The noncollagenous matrix proteins (NCPs) of these tissues are intimately involved, both temporally and spatially in mineralization, including the processes of mineral nucleation and control of crystal growth [1]. In these later processes, one group of NCPs, dentin phosphoproteins (DPPs), have been the subject of considerable scientific attention because of their apparent ability to stimulate or inhibit mineral formation [2-6].

Dentin sialoprotein (DSP) has been suggested to have a function in dentin mineralization [2], but its precise role is currently unknown. However, DSP mRNA expression and secretion of the protein itself are associated with dentin mineral formation [7]. In addition, the existence of a single gene coding for both DSP and DPP suggests that the functional roles of these two NCPs may also be tightly coupled with respect to dentin mineral nucleation [8].

A highly phosphorylated DPP, phosphophoryn, has been isolated from mammalian dentin, including human tissue [9-12], and is comparatively abundant in dentin ( $>50 \%$ in the rat, possibly less in humans). Phosphophoryn, by convention, has $>75-80 \%$ of its amino acid residues as aspartic acid and (phos) serine residues, and under conditions of physiological $\mathrm{pH}$ and ionic strength, phosphophoryn will nucleate apatite crystals $[3,4,5]$. This is perhaps, related to phosphophoryn acting as a template for biomineralization. However, its activity may be dependent on its molecular structure, that is, whether it is folded or unfolded, which in turn may be $\mathrm{pH}$-dependent [13]. It has also been reported that phosphophoryn binds to the gap region of Type 1 collagen fibrils and initiates plate-like apatite crystal formation [14]. Further, phosphophoryn has been suggested to affect crystal growth and so influence crystal morphology by several but probably related mechanisms: by binding to ions or ion clusters; stabilizing the crystal nucleus; binding to the 100 face of growing apatite crystals; and/or binding to multiple growth sites [15-18]. 
It has also been suggested that the degree of phosphorylation of phosphophoryn has marked effect on both collagen Type I fibrillogenesis and mineral nucleation [19-22]. Loss of phosphate groups may occur during the natural extracellular enzymic processing and degradation of the protein following dentin mineralisation [10, 23-25]. Results of other studies have shown that this degraded protein has to be removed before remineralization can occur in completely demineralized samples of human dentin $[26,27]$. This suggests that the "quality" of phosphophoryn, in terms of molecular form and structure, exerts a significant effect on mineral nucleation and crystal growth.

Protein-mineral binding is thus likely to play a central role in the biomineralization process. Wierzbicki et al. [28] using atomic force microscopy (AFM), observed proteins on calcite crystal surfaces. They described oyster shell protein as having a globular appearance on the crystal surface, whereas poly (Asp) was extended on the surface, giving it a layering effect. More recently the conformation of dentin phosphophoryn adsorbed to hydroxyapatite crystals using high-resolution solid-state nuclear magnetic resonance (NMR) spectroscopy was investigated [29]. It was concluded from this study that phosphophoryn may be an extended structure on the surface of those crystals and the $\beta$-sheet-like structure, favored by the molecular modeling studies [30], resembles locally the predicted structure of $[\mathrm{Asp}-\mathrm{Ser}(\mathrm{P})-\mathrm{Ser}$ $(-\mathrm{P})]_{\mathrm{n}}[31]$

It is probable that binding of proteins to developing hydroxyapatite crystals is governed by the interaction between specific protein motifs and charge domains on the crystal surfaces. Using chemical force microscopy (CFM) Kirkham et al. [32] have recently reported that the surfaces of developing enamel crystals carry a net positive charge, interrupted by small $(\sim 15$ $\mathrm{nm}$ wide) areas of negative charge or lower positive charge density, perpendicular to the c-axis and separated by $30-50 \mathrm{~nm}$ along the c-axis. Such charge domains may therefore be candidate sites for matrix-mineral interactions.

In order to test this hypothesis, Kirkham et al. [32] investigated the possible relationship between the charge arrays on crystal surfaces and matrix-mineral binding using the AFM in fluid-tapping mode. These images revealed individual molecules or molecular aggregates for both serum albumin and amelogenin aligned on crystal surfaces, with spatial distributions correlating closely with the previously identified charge domains.

This system can also be used to provide a measure of protein-mineral binding by rinsing through the AFM fluid cell using phosphate buffers of increasing ionic strength to determine the point at which the proteins are desorbed [33, 34]. The data can be quantitated by measuring surface roughness of the crystals at all stages of the process.
The overall aim of the present study was to use the AFM in fluid tapping mode to investigate the interaction of dentin proteins with natural crystals of biological hydroxyapatite. Developing enamel crystals were used as a source of biological mineral for this purpose. The specific aims of this work were to

1. determine whether dentin protein-crystal binding was related to the charge domains recently described on developing enamel crystal surfaces;

2. compare the mineral binding capacity of DSP and phosphophoryn in order to determine whether the roles for these proteins in mineral nucleation and control of crystal growth are similar;

3. determine whether dephosphorylation of phosphophoryn affected its binding capacity

\section{Methods}

\section{Proteins Used In Binding Experiments}

Purified and biochemically characterized dentin phosphophoryn was obtained from immature tooth roots of human permanent teeth after demineralization in $10 \%$ EDTA. The resulting extract was desalted and DPP purified using $\mathrm{CaCl}_{2}$ precipitation, DE4E-saphorose chromatographs, followed by $\mathrm{MgCl}_{2}$ precipitation [35]. DSP was obtained, purified, and characterized from similar specimens using the method described by Butler et al. [36]. Dephosphorylation of phosphophoryn was carried out using alkaline phosphatase (ALP). Human phosphophoryn was dissolved in $0.1 \mathrm{M}$ Tris- $\mathrm{HCl} \mathrm{pH} 8.0$ and incubated with bovine intestinal ALP attached to agarose beads. The beads containing the enzyme were removed by centrifugation and the phosphate content was analyzed. It was found necessary to carry out the dephosphorylation twice to ensure its completeness [19]. Dentin proteins, obtained as described above, were dissolved in $20 \mathrm{mM}$ Tris to a final concentration of $50 \mu \mathrm{g} / \mathrm{ml}$. The $\mathrm{pH}$ of the solution was then adjusted to $\mathrm{pH} 7.4$ by titration with small quantities of dilute $\mathrm{HCl}$.

\section{Enamel Crystals}

Small particles (approximately $50-100 \mu \mathrm{g}$ in weight) of maturation stage enamel were micro-dissected free from the underlying dentin and used for the isolation of individual crystals. The enamel particles were first extracted with $0.1 \mathrm{M}$ sodium phosphrate buffer, $\mathrm{pH} 7.4$ to desorb mineral bound and freely mobile protein species. The insoluble residue after extraction was pelleted by centrifugation and the supernatant removed. This was repeated for a total of 6 times. The pelleted material was then futher extracted in $50 \mathrm{mM}$ Tris containing $4 \mathrm{M}$ urea at neutral $\mathrm{pH}$ to dissolve aggregated protein. This extraction was also repeated 6 times with $0.1 \mathrm{M}$ phosphurate buffer, $\mathrm{pH} 7.4$, to ensure final desorbtion of any mineral-bound components. The final extraction used distilled water with the $\mathrm{pH}$ adjusted to 7.0 in order to remove all traces of buffer and urea. Centrifugation and resuspension of the pellet was again repeated 6 times. Removal of protein from the crystals was monitored spectrophotometrically at $216 \mathrm{~nm}$ and by polyacrylamide gel electrophoresis of the extraction solutions and following total dissolution of aliquots of the crystals using acetic acid [37-39].

Protein-crystal binding. The enamel crystals were sonicated for $2 \mathrm{~min}$ in HPLC-grade methanol to prevent aggregation [40]. Approximately $2 \mu \mathrm{l}$ of this suspension was then placed onto freshly cleaved mica (Agar). The methanol was evaporated rapidly leaving a spread of dispersed hydroxyapatite crystals 
on the surface. Fifty microliter of protein solution (phosphophoryn, DSP, or dephosphorylated phosphophoryn) for 120 sec was then added and the sample was introduced to the AFM fluid cell in the presence of approximately $100 \mu \mathrm{l}$ of distilled water ( $\mathrm{pH}$ 7.4). Crystals not treated with protein acted as controls.

All samples were imaged on a Digital Instruments Nanoscope IIIa Multimode AFM, equipped with an E-type scanner $(\sim 15 \mu \mathrm{m} \times 15 \mu \mathrm{m}$ maximum scan range in $x-y$ direction) using a commercially available fluid cell (Digital Instruments, Santa Barbara, CA). Tapping mode images were obtained using oxide sharpened silicon nitride NP-S cantilevers of quoted spring constant $0.32 \mathrm{~N} / \mathrm{m}$ (Digital Instruments, UK Cambridge) and radii of $5-40 \mathrm{~nm}$ curvature. Cantilevers were resonated at approximately $9 \mathrm{kHz}$ and images obtained at a tapping amplitude of approximately $80 \%$ of free amplitude.

\section{Desorption of Protein from Crystal Surfaces}

Desorption of proteins from the crystal surfaces was achieved using $200 \mathrm{mM}$ phosphate buffer at $\mathrm{pH}$ 7.4. Time-lapsed images of the crystals were then obtained.

\section{Measurement of Surface Roughness}

Surface roughness measurements $\left(\mathrm{R}_{\mathrm{a}}\right)$ were obtained over a length of $50-100 \mathrm{~nm}$ in an approximately central line parallel to the crystal c-axis. A minimum of 20 measurements were obtained in order to achieve a final mean roughness value. $R_{a}$ roughness was calculated using the Nanoscope 4.23 software and is defined here as:

$$
R_{a}=\frac{1}{L_{x} L_{y}} \int_{0}^{L_{y}} \int_{0}^{L_{x}}|f(x, y)| d x d y,
$$

where $f(x, y)$ is the surface relative to the center plane and $L_{\mathrm{x}}$ and $L_{\mathrm{y}}$ are the dimensions of the surface. Therefore the calculated surface roughness in this case is the mean value of the surface relative to the center plane and takes into account any changes in the slope of the crystal surface.

Statistical analysis of the results of the roughness measurements for the protein-coated and non-protein crystal surfaces were analyzed using an unpaired Student's $t$-test.

\section{Results}

Figure 1 shows the image of the enamel crystals before (Fig 1a) and after (Fig 1b, c, \& d) addition of the proteins. Figure $1 b$ and $c$ are images of the enamel crystal preparations following the addition of dephosphorylated phosphophoryn and DSP, respectively. Globular structures ("nanospheres" approximately $50 \mathrm{~nm}$ in diameter) were seen to be distributed on the mica and also in association with the crystal surface, but with no discernible pattern. Figure 1d shows the effect of adding phosphophoryn to the crystals. Phosphophoryn was also present on the surfaces of the mica and the crystals in the form of nanospheres similar in size and appearance to those seen for DSP and the dephosphorylated phosphophoryn. However, phosphophoryn binding gave rise to a distinctive banding pattern to the crystal surface.
The results of protein desorption experiments using $200 \mathrm{mM}$ phosphate solution is seen in Figure 2. Figure 2a shows an image of the control enamel crystal preparation in the absence of proteins and treated with the phosphate buffer solution only. The smooth surface topography of the crystals can be seen. Time-lapsed images of the crystal surfaces after treatment with dephosphorylated phosphophoryn (Fig. 2b) and DSP (Fig. 2c) are shown after desorption with $200 \mathrm{mM}$ phosphate solution. Protein nanospheres still appeared to be present on the mica surfaces but few, if any, were associated with the crystals which appeared very similar to the untreated controls. In contrast, Figure $2 \mathrm{~d}$ shows the effect of phosphate desorption on the same crystals treated with phosphophoryn shown in Figure 1d. Distinct "banding" was again observed, apparently related to the retention of the phosphophoryn nanospheres on the enamel crystal surfaces.

Measurement of surface roughness of the crystals and crystal-protein preparations confirmed these observations, providing quantitative data, as shown in Table 1. Significant differences were observed in surface roughness following the addition of phosphophoryn to the crystals, which became rougher as a result. This increase in roughness was still present even after the addition of phosphate buffer. Addition of dephosphorylated phosphophoryn increased surface roughness in comparison with the crystals alone but this did not prove significant when tested. There was also no significant, effect when DSP was added to the crystals. Surface roughness after desorption of the dephosphorylated phosphophoryn, when compared to the crystal only control, decreased significantly.

\section{Discussion}

These AFM images are the first to show the interaction of dentin proteins from human teeth with naturally derived crystals of hydroxyapatite mineral. Ideally, imaging such interactions for phosphophoryn and DSP should be done using dentin crystals as the mineral source, but there are technical challenges that have yet to be overcome to permit this. Isolation of crystals from dentin without significantly altering their surface characteristics is extremely difficult due to the presence of the collagenous matrix within the tissue. In addition, the size of individual dentin crystals is extremely small, and anchoring them to substrates for scanning under fluid in the AFM remains a problem. For these reasons, crystals derived from developing enamel have been used in this study. These crystals are larger than those of dentin and offer the opportunity of using biological apatite to determine mineral-matrix associations, with the additional advantage of a previously characterized surface chemistry. 
(a)

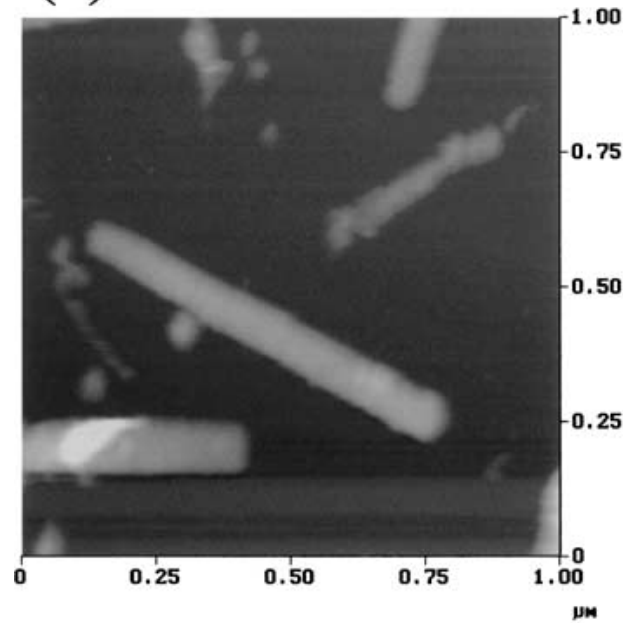

(c)

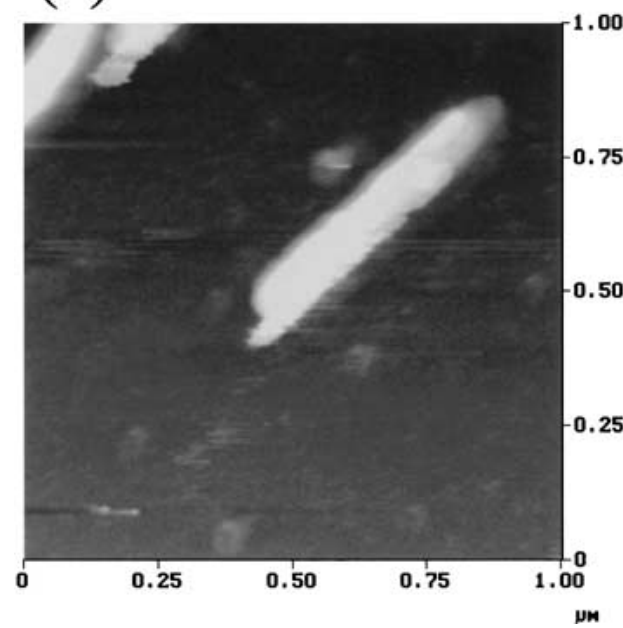

Tapping mode AFM images of maturation stage enamel crystals before and after the binding of dephosphorylated phosphophoryn, DSP, and phosphophoryn, imaged after the exchange of the solutionin the fluid cell with $200 \mathrm{mM}$ phosphate buffer ( $\mathrm{pH}$ 7.4) (a) Crystals imaged prior to the intro-

(b)

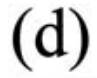

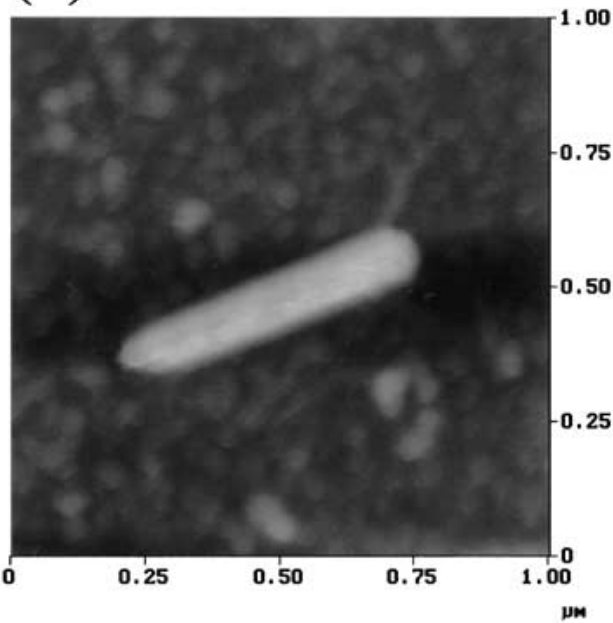

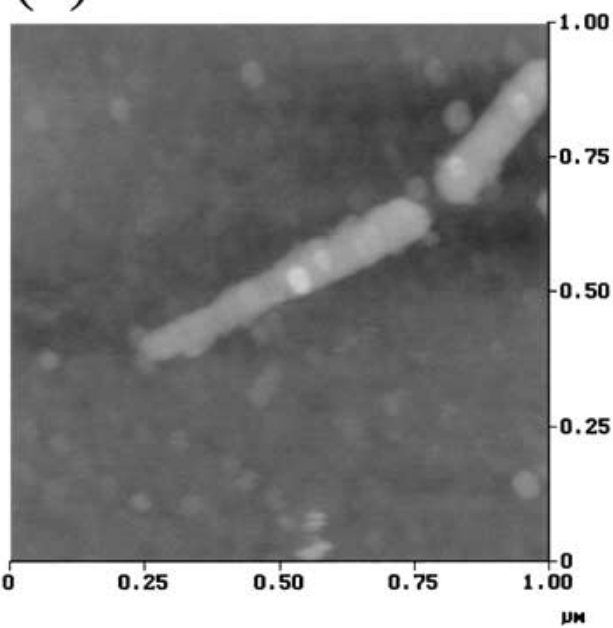

duction of protein in buffer. (b) Crystals imaged after the introduction of dephosphorylated phosphophoryn and then buffer. (c) Crystals imaged after the introduction of DSP and then buffer. (d) Crystals imaged after the introduction of phosphophoryn and then buffer.

Table 1. Surface roughness $(\mathrm{Ra})$ measurements of developing enamel crystals in the presence or absence of dentin matrix proteins and \pm treatment with $200 \mathrm{mM}$ phosphate buffer

\section{Sample}

Crystal only (control)

Crystal + phosphophoryn

Crystal + dephosphorylated phosphophoryn

Crystal + DSP
$\mathrm{Ra}(\mathrm{nm})$ in water, $\mathrm{pH} 7.4$

$\mathrm{Ra}(\mathrm{nm})$ in $200 \mathrm{mM}$ phosphate buffer, $\mathrm{pH} 7.4$
$0.78 \pm 0.26 \mathrm{n}=50$

$1.10 \pm 0.33^{\mathrm{a}} \mathrm{n}=44$

$0.54 \pm 0.15 \mathrm{n}=40$

$0.72 \pm 0.31 \mathrm{n}=42$

Results show mean \pm SD

${ }^{\mathrm{a}}=$ significantly different from control $(P<0.01)$ 
"banded" appearance is similar to that described for amelogenin [32] and for bovine serum albumin [42]. This banding appears most clearly on the upper crystal in Figure 1d, the phosphophoryn-treated specimen. Banding was apparent on other crystals treated with phosphophoryn and after desorption, but some of the resolution is lost in capturing the images. This concept, however, is supported in part by the roughness data. These bands seem to be of a similar periodocity to the charge arrays described by these authors using chemical force microscopy.

The results of the protein desorption experiments using $200 \mathrm{mM}$ phosphate buffer would suggest that both the dephosphorylated phosphophoryn and DSP have less affinity for hydroxyapatite crystals than phosphophoryn. In fact, their distribution at the crystal surface may be a random event rather than any true binding to the enamel surface. The failure of the phosphate solution to desorb the phosphophoryn from the crystal surfaces would suggest that the interaction between phosphophoryn and the crystal surfaces is very strong. The surface roughness measurement, after the desorption of the dephosphorylated phosphophoryn, decreased significantly compared with the crystal only control (Table 1). Imaging in the presence of proteins is technically very challenging because of tip contamination which effectively decreases resolution. Thus, an explanation for the apparent smoother surface of this specimen is because of tip contamination when determining surface roughness. Again, the important comparator is with the protein-treated samples in the same experiment group, which in this case, are significantly rougher.

The high affinity of phosphophoryn for hydroxyapatite crystal surfaces certainly suggests a role for this protein in the control of crystal growth. These results also suggest that phosphorylation of phosphophoryn appears to be playing an important part in this "binding" to the crystal. This appears to be partially borne out by the work of Fujisawa et al. [20] who found that dephosphorylated phosphophoryn precipitated less calcium ions than the intact protein. The adsorption capacity of phosphophoryn onto hydroxyapatite was diminished by reducing the acidic groups due to dephosphorylation. This affinity may also be affected by the phosphophoryn concentration [45] and $\mathrm{pH}$ [46] both of which will affect intramolecular folding. There is less evidence to suggest that DSP would play such a role. It is less affinity for the crystal surfaces than phosphophoryn, and although dentin sialophosphoprotein (DSPP) is a unique molecule produced by a single gene, dspp, the ratio of DSP to phosphophoryn in dentin is $1: 8-10$, suggesting early degradation of this protein [47]. DSP has also been introduced into an in vitro mineralization system where it had a limited effect on apatite formation and growth. The authors also reported that DSP has a low affinity for hydroxyapatite seed crystals, which supports the AFM observations [48]. Certainly, other dentin matrix proteins, such as the proteoglycans, could be studied in the AFM using an enamel crystal protein desorption model.

In summary, although both DSP and phosphophoryn may promote mineral nucleation, it is less likely that DSP plays a continuing role in controlling subsequent crystal growth. However, phosphophoryn is a more likely candidate in controlling dentin crystal growth and morphology based on its high affinity for the crystal surfaces. This role is probably dependent upon its degree of phosphorylation, implying a mechanism for extracellular matrix modification in the control of biomineralization in skeletal tissues.

\section{References}

1. Butler WT, Ritchie H (1995) The nature and functional significance of dentin extracellular matrix proteins. Int $\mathbf{J}$ Dev Biol 39:169-179

2. WTButlerDentin matrix proteins. (1998) Eur J Oral Sci (suppl 106)1:204-210

3. Boskey AL, Muresca S, Doty S, Sabsay B, Veis A (1990) Concentration-dependent effects of dentin phosphophoryn in the regulation of in vitro hydroxyapatite formation and growth. Bone Miner 11:55-65

4. Lussi A, Crenshaw MA, Linde A (1988) Induction and inhibition of hydroxyapatite formation by rat dentine phosphoprotein in vitro. Arch Oral Biol 33:685-691

5. Linde A, Lussi A, Crenshaw MA (1989) Mineral induction by immobilized polyanionic proteins. Calcif Tissue Int 44:286-295

6. Hunter G, Hauschka P, Poole A, Rosenberg L, Goldberg H (1996) Nucleation and inhibition of hydroxyapatite formation by mineralized tissue proteins. Biochem J 317: 5964

7. Ritchie H, Wang LH (1997) A mammalian bicistronic transcript encoding two dentin-specific proteins. Biochem Biophy Res Comm 231:425-428

8. Gu K, Chang SR, Ritchie HH, Clarkson BH, Rutherford RB (2000) Molecular cloning of a human dentin sialophosphoprotein gene. Eur J Oral Sci 108:35-42

9. Crossley MA, Huq NL, Kirszbaum L, Reynolds EC (1996) Purification and n-terminal analysis of bovine dentin phosphophoryn. J Dent Res 75:154

10. McCurdy SP, Clarkson BH, Feagin FF (1992) Comparison of phosphoprotein isolated from mature and immature human tooth roots. Arch Oral Biol 37:1057-1065

11. MacDougall M, Ziechner-David M, Starkin HCS (1989) Characterization of extracellular and nascent dentin phosphoprotein. Connect Tissue Res 22:71-77

12. Stetler-Stevenson WG, Veis A (1983) Bovine dentin phosphophoryn: composition and molecular weight. J Biochem 18:4326-4335

13. Evans JS, Chan SI (1994) Phosphophoryn, a biomineralization template protein: $\mathrm{pH}$-dependent protein folding experiments. Biopolymers 34:507-527

14. Traub W, Jodaikin A, Arad T, Veis A, Sabsay B (1992) Dentin phosphoryn binding to collagen fibrils. Matrix 12:197-201

15. Termine JD, Eanes ED, Conn KM (1980) Phosphoprotein modulation of apatite crystallization. Calcif Tissue Int 21:247

16. Addadi L, Weiner S (1985) Interactions between acidic proteins and crystals: stereo chemical requirements in biomineralization. Proc Nati Acad of Sci of USA 82:4110 4411

17. Addadi L, Moradian-Oldak J, Fured-Milhofer HI, Weiner S, Veis A (1992) Sterochemical aspects of crystal regulation 
in calcium phosphate-associated mineralized tissue. In: Slavkin H, Proce P (eds) Chemical Biology of Miner Tissue, pp 153

18. Boskey AL (1991) The role of extracellular matrix components in dentin mineralization. Crit Rev Oral Biol 2:369387

19. Clarkson BH, McCurdy SP, Gax D, Hand AR (1993) Effects of phosphoprotein on collagen fibril formation in vitro. Arch Oral Biol 38:737-743

20. Fujisawa R, Kuboki Y, Sasaki S (1986) Changes in interaction of bovine dentin phosphophoryn with calcium and hydroxyapatite by chemical modification. Calcif Tissue Int $39: 248$

21. Saito T, Yamauchi M, Crenshaw MA (1998) Apatite induction by insoluble dentin collagen. J Bone Miner Res 13:265-270

22. Saito T, Arsenault AL, Yamauchi M, Kuboki Y, Crenshaw MA (1997) Mineral induction by immobilized phosphoproteins. Bone 21:305-311

23. Linde A, Bhown M, Butler WT (1980) Non-collagenous protein content of rat incisor and permanent bovine dentin. Scand J Dent Res 96:188-189

24. Masters PM (1983) Stereochemically altered non-collagenous protein from human dentin. Calcif Tissue Int 35:43-47

25. Masters PM (1985) In vivo decomposition of phosphoserine and serine in non-collagenous protein from human dentin. Calcif Tissue Int 37:236-241

26. Clarkson BH, Feagin FF, McCurdy SP, Sheetz J, Speirs RL (1991) The effects of phosphoprotein moieties on the remineralization of human root caries. Caries Res 25:166173

27. Clarkson BH, Chang SR, Holland GR (1998) Phosphoprotein analysis of sequential extracts of human dentin and the determination of the remineralization potential of these dentin matrices. Caries Res 32:357-364

28. Wierzbicki A, Sikes CS, Madura JD, Drake B (1994) Atomic force microscopy and molecular modeling of protein and peptide binding to calcite. Calcif Tissue Int 54:133-141

29. Fujisawa R, Kuboki Y (1998) Conformation of dentin phosphophoryn adsorbed on hydroxyapatite crystals. Eur J Oral Sci 106:249-253

30. Dahlin S, Angstrom J, Linde A (1998) Dentin phosphoprotein sequence motifs and molecular modeling: conformational adaptations to mineral crystals. Eur J Oral Sci 106:239-248

31. George A, Bannon L, Sabsay B, Dillon JW, Maline J, Veis A, Jenkins NA, Gilbert DJ, Copeland NG (1996) The carboxyl-terminal domain of phosphophoryn contains unique extended triplet amino acid repeat sequences forming ordered carboxyl-phosphate interaction ridges that may be essential in the biomineralization process. $\mathbf{J}$ Biol Chem 271:32869-32873

32. Kirkham J, Zhang J, Brookes SJ, Shore RC, Wood SR, Smith DA, Wallwork ML, Ryu OH, Robinson C (2000) Evidence for charge domains on developing enamel crystal surfaces. J Dent Res 79:1943-1947
33. Gorbunoff M (1984) The interaction of proteins with hydroxyapatite I. The role of charge and structure. Anal Biochem 136:425-432

34. Gorbunoff M, Timasheff S (1984) The interaction of proteins with hydroxyapatite III. Mechanism. Anal Biochem 136:440-446

35. Chang SR, Chiego Jr D, Clarkson BH (1996) Characterization and identification of a human dentin phosphophoryn. Calc Tissue Int. 59:149-153

36. Butler WT, Bhown M, Dimuzio M, Linde A (1981) Noncollagenous proteins of dentin. Isolation and partial characterization of rat dentin proteins and proteoglycans using a three-step preparative method. Coll Res 1:187199

37. Hiller CR, Robinson C, Weatherell JA (1975) Variations in the composition of developing rat incisor enamel. Calcif Tissue Res 18:1-12

38. Robinson C, Brookes SJ, Kirkham J, Bonass WA, Shore RC (1996) Crystal growth in dental enamel: the role of amelogenins and albumin. Adv Dent Res 10:173-180

39. Kirkham J, Brookes SJ, Shore RC, Bonass WA, Smith DA, Wallwork ML, Robinson C (1998) Atomic force microscopy studies of crystal surface topology during enamel development. Connect Tissue Res 38:91-100

40. Zhang J, , Kirkham J, Wallwork ML, Smith DA, Brookes SJ, Shore RC, Wood SR, Robinson C (1999) Use of selfassembled monolayers as substrates for atomic force imaging of crystals from mammalian skeletal tissues. Langmuir 15:8178-8183

41. Mori O, Imae T (1997) AFM investigation of the adsorption process of bovine serum albumin on mica. Colloids and Surfaces B. Biointerfaces 9:31-36

42. Wallwork ML, Kirkham J, Zhang J, Smith DA, Brookes SJ, Shore RC, Wood SR, Ryu O, Robinson C (2001) Binding of matrix proteins to developing enamel crystals:an atomic force microscope study. Langmuir

43. Chander S, Fuerstenau DW (1984) Adsorption on and surface chemistry of hydroxyapatite. Plenum Press, New York, pp 29

44. Mafe S, Manzencres JA, Reiss H, Thomann JM, Gramawn P (1996) Model for the dissolution of calcium hydroxyapatite powder. J Phys Chem 96:861-866

45. Stetler-Stevenson EG, Veis A (1987) Bovine dentin phosphophoryn: calcium ion binding properties of a high molecular weight preparation. Calcif Tissue Int 40:97102

46. Boonstra ED, ten Bosch JJ, Arends J (1992) Adsorption of dentine proteins onto spheroidal calcium phosphate in a neutral and in an acidic environment $\mathbf{J}$ de Biol Buccale 20:111-116

47. Ritchie HH, Ritchie DG, Wang LH (1998) Six decades of dentinogenesis research. Historical and prospective views on phosphophoryn and dentin sialoprotein. Eur J Oral Sci 106:211-220

48. Boskey A, Spevak L, Tan M, Doty SB, Butler WT (2000) Dentin sialoprotein (DSP) has limited effects on in vitro apatite formation and growth. Calcif Tissue Int 67:472-478 